\title{
The Neutralization of Tropes in Fairy Tale Narratives
}

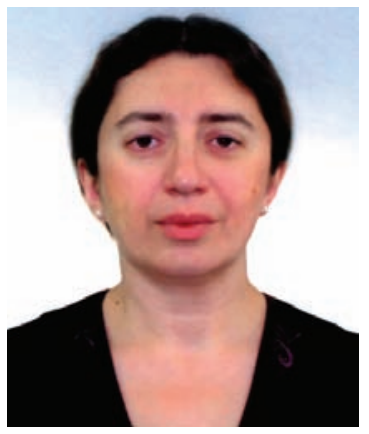

Alvard Jivanyan
Y uri Lotman has once commented on the propensity of the Romantics to get rid of tropes. It is possible that this tendency could be accounted for by their deep love of the fairy tale, for one of the important stylistic features of the fairy tale is its tendency to neutralize tropes at the expense of the intentional enlivening of their worn, hackneyed semantics. ${ }^{1} \mathrm{~A}$ very similar process was observed by Zvetan Todorov in his major study of the fantastic where he examines the different ways that connect the figures to the fantastic. In a detailed analysis of William Beckford's Vathek he comments that the supernatural appears as an extension of a rhetorical figure, realizing the literal sense of a figurative expression (Todorov,

1975: 79). Further he extends this important observation on the whole genre of the fantastic:

... we are not concerned here with an individual feature of style, but with a property linked to the structure of the fantastic as a genre.

The different relations that we have observed between the fantastic and figurative discourse shed light on each other. If the fantastic constantly makes use of rhetorical figures, it is because it originates in them. The supernatural is born of language. It is both its consequence and its proof...The supernatural thereby becomes a symbol of language, just as the figures of rhetoric do, and the figure is, as we have seen, the purest form of literality (Todorov, 1975: 82).

As a result of the process of animation the figurative meaning of the trope is neutralized. From a stylistic device it changes into a narrative device, giving the story a powerful push forwards. It is true the studies related to the animation of tropes are mainly carried out in the domain of the fantastic (Todorov, 1975) and the literary fairy tale (Sutherland, 1970; Dobzinska, 1990), however, to a large degree the conclusions these scholars came to are relevant in the case of the traditional fairy tale too, especially if we admit that in its broadest sense the folk fairy tale can be held as fitting in the genre of the fantastic.

Normally, in cases described above only the animated phrase is present in the text whereas the rhetorical figure itself may be absent. Many of them can be easily restored owing to the fact that they are hackneyed figures known to the listeners or readers. However, in such instances it is difficult to state the type of the extended trope, for the animation of both simile and metaphor can result in identical structures. To use the terms of Zvetan Todorov, the animated phrase and the figure can be said to be in "diachronic" relations. Here is a folk tale passage where the animation of the simile tears flew like a 
river is rather obvious. The passage is taken from the Armenian tale The Wicked Woman. It was recorded by Margarit Grigorian in 1949 and included into her collection of Artsakh (Nagorno Karabakh) folk tales. The teller is a peasant woman Araksya Hambardsumian. A poor maiden is persecuted by her mischievous step mother for having lost a piece of bread. After futile efforts to find the lost bread she proceeds to the forest:

Crying bitterly she wandered and looked for the lost bread. She cried so much that her tears became a river and flowed. The waters of that river reached a shepherd. The shepherd drank of the river and felt it was salty. At this he was very surprised and decided to find out where the water was coming from. He walked a long way and a short way and finally saw a girl who was crying bitterly (Abrahamian, 1966: 615).

The quoted phrase her tears became a river is to be understood and interpreted literally. In case of alternative, i.e. metaphoric interpretation, the succeeding text may be under threat of logical and semantic collapse. ${ }^{2}$

The magic transformation of tears into a river has a distinct narrative function: only through a river of tears can the step daughter reach the shepherd and be rescued from the persecutions of her cruel step parent. It is interesting that Max Lsthi writing about the lack of descriptions of the emotional state of folk tale personages has rightly commented on a related tale text:

If a folktale hero sits down crying on a stone because he is at a loss over how to help himself, we are not told this so as to be shown the state of his soul, but because in such a situation it is just this kind of reaction on the part of the hero that leads to contact with an otherworld helper (Lbthi, 1986: 14).

It is also possible to claim that the river in this example is a disguised temporal unit paralleling the flow of time. Sorrow becomes a unique time module: tears turn into a repetitive pattern measuring it. On such a backdrop Cummings's famous a grief ago seems more understandable. It is a well known fact that the fairy tale narrative seldom includes accurate temporal information. It prefers specific, often oblique means of denoting time continuum. The passage of time here can be covertly implied with the help of iron boots getting worn, a handful of raisins being eaten etc.

To compare, we consider an analogous episode from Tattercoats included into Joseph Jacob's collection of English fairy tales. Here tears are shown as a time pattern even more explicitly:

So he turned his back, and sat by his window looking out over the sea, and weeping great tears for his lost daughter, till his white hair and beard grew down over his shoulders and twined round his chair and crept into the chinks of the floor, and his tears, dropping on to the window-ledge, wore a channel through the stone, and ran away in a little river to the great sea (Jacobs, 1993: 281). 
As in the Armenian example, it is possible to claim that the phrase his tears, dropping on to the window-ledge, wore a channel through the stone, and ran away in a little river to the great sea emerges at the expense of the animation of a trope (either a simile, tears flew like a river, or a hyperbole, a river of tears etc). The window through which the river of tears flows towards the sea may stand as a masked metaphor for the eye shedding tears.

In fewer tales the original rhetorical figure is present. The tale shows the tropes and their animation in the same textual cut. Here, to use Todorov's definition, we are faced with "synchronic" relations:

...the figure and the supernatural are present on the same level, and their relation is functional, not "etymological". Here the appearance of the fantastic element is preceded by a series of comparisons, of figurative or simply idiomatic expressions, quite common in ordinary speech but designating, if taken literally, a supernatural event - the very one that will occur at the end of the story (Todorov, 1975: 79).

The following stretch of narrative is taken from the Armenian folk tale Sadaphia Khanum (Lady Mother-of-Pearl). It was recorded by Gevorg Sherents and included into his beautiful collection of Van (historical Armenia) folk tales. The teller is unknown:

By lord's command the maiden jumped out of the sea hollow. The sea waves took her and brought to a piece of land. She looked around and saw nothing except the bottomless sea and the vast fields. Neither men nor beasts could be seen. Sometimes birds would come down from the sky and then fly back again. The maiden cried, cried and the tears from her eyes flew down and fell around her like beads of pearl - so much for the maiden.

Another Queen had sworn that if she could have a boy child may it remain in the shape of a bird for seven years, see the whole world and then only marry the girl he wanted. Now the six years had already passed. Once the prince came down the island and what did he see there but a fairy like girl. She was helpless? naked and bare-footed, hungry and thirsty. Immediately the bird flew to houses which had laundry hanging on the lines and stole some clothes from here and there and covered the girl's body. Her tears, which had turned into pearls, he gathered and put into a box. Then he took the maiden on his wings and flew her to his house (Sherents, 1899: 101).

In the quoted passage we can easily identify the expression the tears from her eyes fell down like beads of pearls as a simile. Further in the narrative the tears change into real pearls. It is interesting that this transformation is represented by the narrator in a rather casual way which is seen even on the level of syntax: it is set in a subordinate clause. This transformation is important on the narrative level. It is not by chance that the bird-man puts the tears which had been changed into pearls into a box and keeps them. Later they could serve as a kind of proof of her grief for losing her lover, as tokens 
of her devotion to him. The box is not unlike the lachrymal vases or tear bottles in Oriental cultures meant to show the truthfulness and love of the wife for her absent husband.

The pearls stored in the box would also serve as a proof of her purity. As the further narrative proves the young woman marries the bird prince but remains untouched and true to her first spouse.

In times old and new tears of a woman have been associative of womanliness. In many cultures the brides are supposed to cry at the wedding party. There seems to exist an almost misogynic belief stating: the crying woman is a beautiful woman. This attitude is relevant in our days too. ${ }^{3}$

It is important to mention that the extension of rhetoric figures is not merely a means of developing the story but also reveals implicit layers of characterization which may remain blocked in case the rhetoric figure were not animated. Fairy tale heroines crying in pearl tears are very often renounced children, daughters of absent or passive fathers, offspring of abandoned women. Though the father in this tale does not literally renounce his daughter, he does not object to the readiness of his wicked spouse to give the girl to be devoured by the snake - prince. The only help the girl may hope to get is the advice of her late mother. In many tales the gift of crying in pearl tears is bestowed upon the girl child at her very birth or at the christening:

One day three women came to their house. Each of them made a good wish for the child. The first woman said, "I will give her such a beauty that whoever sees her will be enchanted and will love her immensely". The second woman said, "I will give the girl strength to grow in a day as much as other children grow in a year. When she cries may pearls drop of her eyes instead of tears. When she laughs may roses and violets fall down from her mouth. And may precious stones appear on the ground she treads on". The third woman said, "I am giving her a cross which will make her immortal as long as she keeps it hung from her neck” (Abrahamian, 1966: 42).

Curiously, similar episodes in their turn can be understood allegorically as they are reminiscent of actual baptismal rites current in Armenia until now: when a girl child is being christened, those present cast some gold and pearls into the baptismal water.

To confirm the view narrated above let us mention that the tale Lady Mother of Pearl includes other story elements denoting at the heroine's status of a renounced daughter. Heeding to the advice of her deceased parent the girl dresses herself in a hedgehog's skin.

"Girl", she said, "why are you crying? Get up and listen to what I will tell you." When they take you to the King's palace ask them to give you a hedgehog's skin. Draw the skin on your face, sit right in front of the snake and look into its eyes (Sherents, 1899).

Apart from its defensive function an animal skin has a very distinct signification in a great number of fairy tales. It points at the status of the disowned child, mostly a female 
child. In this particular tale the girl herself admits and exposes her disgrace, the disgrace of being cast in front of a monster as food by her own parents. The disgrace of being renounced may suggest a voluntary self-abasement, a self-willed deed acknowledging and displaying the hurting status of the disowned. Comparable examples can be easily found in folklores of most cultures.

At the same time, wearing animal skins or plant clothes instead of proper outfits is a kind of silent reproach, a challenge addressed to the cruel or, in this case, indifferent parent. No wonder in some fairy tales the degraded characters clad in strange clothes conceal their former names, in this manner renouncing their descent and their parents, the father in the first place. ${ }^{4}$ Thus before marrying the snake prince the heroine is nameless.

Wearing habits made of animal furs, skins or plants is renouncing also one's own kind and even hints at a partial shape shifting. The heroine chooses to show herself as a beast, a non-human. Where a human is under threat coming from his likes, an animal or a plant can survive. It is not accidental that in several tales of the Donkeyskin cycle the personage does not merely wear an animal skin but actually changes into one.

It is true wearing unusual clothes might have another signification in fairy tale narratives: it implies the character's pre-matrimonial status, her passage from maidenhood to womanhood, the temporary fall before achieving a higher, royal status through marrying a prince. Ruth Bottigheimer defines such stories as restoration tales (Bottigheimer, 2002: 11).

Wearing herbal clothes means that one is not dressed properly but is not naked either. In this sense tales of this series remind very much those relating of the clever maiden expected to be taken to marriage on condition she appears neither dressed nor naked, to put the marriage condition into Grimms' words: komm zu mir nicht gekleidet, nicht nackend... und wenn du das kannst, will ich dich heiraten.

Understandably, in the case of synchronic arrangement of the figure and its extension, the animated phrase succeeds the rhetoric figure. Probably a unique case when the animated phrase precedes the trope is found in Grimms' Mother Hulda:

What are you afraid of, my dear child? Come and live with me, and if you do the house-work well and orderly, things shall go well with you. You must take great pains to make my bed well and shake it up thoroughly, so that the feathers fly, and then in the world it snows, for I am Mother Hulda (Brothers Grimm, 1993: 207).

And further

As the old woman spoke so kindly, the girl took courage, consented, and went to her work. She did everything to the old woman's satisfaction, and shook the bed with such a will that the feathers flew about like snow flakes: and so she led a good life, had never a cross word, but boiled and roast meat every day (Grimm, 1993: 129).

Here the order of appearance of the mentioned structures is reversed and it is permissible to conclude that the reversion was done owing to the interference of the 
recorders. The folk version would hardly have a simile succeeding the transformation as this makes the text redundant in terms of narrative logic.

Often relations between a figure and its extension are revealed in two different versions of the tale or tales of different types. The tale Nouri Hadig (The Pomegranate Seed), the Armenian version of Snow White involves an implicit comparison of the young heroine's beauty to a pomegranate. She is as white and red as a pomegranate. This version was recorded by S. Hoogasian in the USA from the words of her grandmother, a Van (historical Armenia) immigrant:

There was once a rich man who had a very beautiful wife and a beautiful daughter called Nourie Hadig (tiny piece of pomegranate). Every month when the moon appeared in the sky, the wife asked: "New moon am I the most beautiful or are you?"

And every month the Moon replied, "You are the most beautiful".

But when Nourie Hadig came to be fourteen years of age, she was so more beautiful than her mother that the moon was forced to change her answer. One day when the mother asked the moon her constant question, the Moon answered: "I am not the most beautiful nor are you. The father's and mother's only child Nourie Hadig is the most beautiful of all." Nourie Hadig was ideally named because her skin was perfectly white and she had rosy cheeks. And if you have ever seen a pomegranate, you know that it had red pulpy seeds with a red skin which has a pure white lining (Hoogassian, 1982: 85).

Another version of this tale which is recorded in Van, almost a century before Hoogassian published her tale, explains the origin of the child's name differently.

There was and there was not a woman. One day she was sweeping the couch and found on it a grain of pomegranate which she threw into her mouth and ate. By the end of nine years, nine minutes and nine months she gave birth of a fairylike pretty daughter and called her Nar Khatyun

(Pomegranate Queen, v.14: 543).

In this version of the tale the comparison is neutralized giving way to the supernatural, the birth of a girl child as a result of swallowing a seed of pomegranate.

It is possible that in folk tales, as different from the literary fairy tale, the dichotomy-trope and its extension are mediated by a masked intermediate, transitional link, mostly a folk belief or some kind of superstition, and the animated phrase is the extension of not so much the rhetoric figure but the folk belief. If we consider the above quoted passages we will see that the simile a girl as red and white as a pomegranate and the extended phrase $a$ girl is born from a pomegranate seed are interceded with the folk belief according to which many Armenian women, when pregnant, crave for pomegranates possibly owing to the sour-sweet taste of this succulent fruit and its highly nutritional value. Additionally, this belief is paralleled by others stating the appearance 
of the child to be born depends on the food the pregnant mother craves for or looks at. ${ }^{5}$

It will not be far-fetched to assume there should have been a folk medical belief according to which if a pregnant mother eats pomegranate she will bear a beautiful child. ${ }^{6}$

In many tales this fruit denotes outstanding, often non-human beauty. Fairy maidens are believed to be enclosed in pomegranates and are born as brides for human Princes. In such cases the fruit serves as a kind of womb where the child is enclosed and is not very different from impregnation from a seed of pomegranate. On the other hand, such narrative episodes can be explained as an echo of child marriages once being in practice in Armenia.

The relations between a trope and its enlivened variant can be observed between tales belonging to diverse cultures. A good example is the German Snow White and the Russian Snegourochka (Snow Maiden). Snow White is as white as snow, Snegourochka is a girl made/born of snow. The two are mediated by the belief that a child's appearance is dependent on things, snow, for example, its mother has looked upon when pregnant. Judging from Alexander Pushkin's version of Snow White, in Russia it was believed that snow gazing would help to bear a white skinned child.

By what right is she my rival?

Such young folly I shall bridle.

So she's grown up - me to spite!

Little wonder she's so white:

With her bulging mother gazing

At that snow - what's so amazing!

(Pushkin, 1973: 3).

Of importance, the translation of analogous tales requires accuracy. Thus one of the oldest Russian translations of Brothers Grimm published in 1893 presents the similative name Snow White as Snegourochka (Snow Maiden, the companion of Ded Moroz, the Russian counterpart of Santa Claus). The seemingly innocuous translation mistake resulted in a rather serious change in the meaning of the story; the human child was transformed into a supernatural creature. This blemish in the translation of the name is explained in the translator's notes to the text where he reveals his wish to find counterparts for the characters in Russian folk culture rather than to translate their names literally (Polevaya, 1893).

An almost identical mistake was found in the Armenian translation of the Grimms. Snow White was translated as Dzunanuysh meaning a snow fairy or a snow maiden. We must admit, though, that the translation error was easily neutralized in the very context of the tale which shows unambiguously that Snow White is the offspring of human parents. Later translators of the tale made an attempt to correct the mistake by coining the literary translation of Snow White Spitakadzunik. Though more accurate, this variant 
sounds rather unnatural in Armenian. At the moment both names are current in Armenian translations of both the Grimm tale and Disney's story. A solution of this problem would probably consist in admitting that the word Dzunanuysh (Snow Maiden) has simply acquired a second meaning a girl as white as snow.

\section{Notes:}

1. It seems important to add that in genres different from the fairy tale, in Nonsense literature, for instance, the enlivening of a trope or a literal understanding of an idiom may not result in the supernatural but will rather create a comic effect. A real river/sea/lake of tears in a fairy tale expresses the sufferings of the personage and at the same time moves the narrative forward. The sea of tears Carroll's Alice and the 'curious animals' swim in is meant to cause a humorous effect.

2. Let us mention that the literal understanding of a narrative does not exclude its possible symbolic interpretation. To have a deeper insight into the meaning of this narrative passage we can refer to a Jungian interpretation. In terms of such an approach, crying is seen as the beginning of initiation which in view of the plot development of numerous similar tales is difficult to disagree with:

Tears are a river that takes you somewhere. Weeping creates a river around the boat that carries your soul-life. Tears lift your boat off the rocks, off dry ground, carrying it downriver to someplace new, someplace better.

...A woman's crying has been considered quite dangerous, for it loosens the locks and bolts on the secrets she bears. But in truth, for the sake of a woman's wild soul it is better to cry. For women, tears are the beginning of initiation into the Scar Clan, that timeless tribe of women of all colors, all nations, all languages, who down through the ages have lived through a great something, and yet who stood proud (Pinkola Estes, 1996: 374).

3. Tears as symbol of womanliness are often used by top fashion designers. In his 1998 show the House of Dior presented an embroidered hair net. The model wearing it had pearl tears on her eyes (L'oficiel, 1998: 16). The Italian firm La Perla advertised women's underwear showing a model with tears flowing down her cheeks; the association between pearls and tears is more than obvious.

4. If placed into the Armenian context namelessness can be accounted for by a different reason. Formerly in certain regions of Armenia girls did not have names but were called by their fathers' names the word daughter added to them.

5. Greeks, for example, used to throw black pepper on expectant mothers on St. Simon's day. This was supposed to cause moles on the child, etc. (Daniels \& Stevans, 1971: 39).

6. Interestingly, in other cultures pomegranate was among the fruit tabooed for the pregnant. According to Daniel's and Stevans's Encyclopaedia of Superstitions, 
Folklore, and the Occult Sciences, the Albanian women are discouraged to eat pomegranate or bad luck will come to their child (Daniels \& Stevans, 1971, 39).

\section{References:}

1. Abrahamian S.(ed.) Char Parave. // Hay Zhoghovrdakan Hekiatner. Yerevan: Akademiayi Hratarakchutyun, 1966, pp. 615-616.

2. Abrahamian S.(ed.) Pirenen Vard Manishak Tapogh Akhchike. // Hay Zhoghovrdakan Hekiatner. Yerevan: Akademiayi Hratarakchutyun 1966, pp. 41-49.

3. Bottigheimer Ruth. Fairy Godfather. // Straparola, Venice and the Fairy Tale Tradition. Philadelphia: University of Pennsylvania Press, 2002.

4. Estes Clarissa Pinkola. Women who Ran Away with the Wolves. London: Rider Books, 1996.

5. Grimm Jacob, Wilhelm. Mother Hulda. // Grimms' Fairy Tales. Hertfordshire, Wordsworth's Children's Classics, 1993, pp.128-131.

6. Hoogasian-Villa Susie. One Hundred Armenian Tales. Wayne State University Press, 1982.

7. Jacobs Joseph. Tattercoats. // More English Fairy Tales. London: Everyman's Library Children's Classics, 1993, pp.281-285.

8. Luthi Max (transl. John D. Niles). The European Fairy Tale. Bloomington and Indianapolis: Indiana University Press, 1986.

9. Pushkin Alexander. The Tale of the Dead Princess and the Seven Knights. Moscow: Progress Publishers, 1973.

10. Sherents Gevorg. Nar Khatyun. // Vana Saz. Tiflis: 1885, vol. 1, pp.106-112.

11. Sherents Gevorg. Sadaphia Khanum. // Vana Saz. Tiflis: 1899, vol. 2, pp. 99-105.

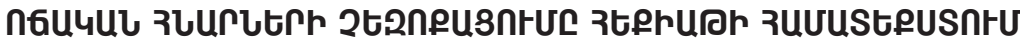

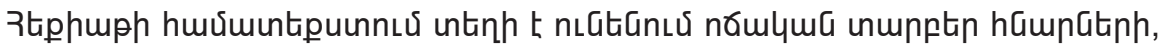

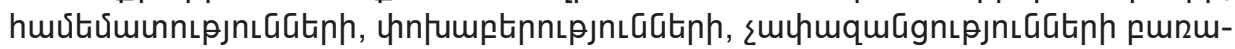

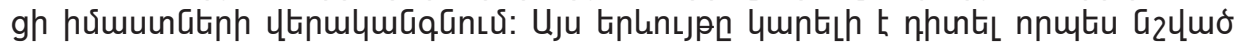

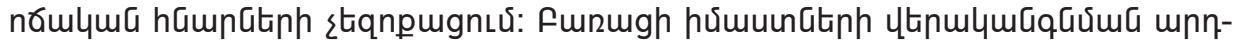

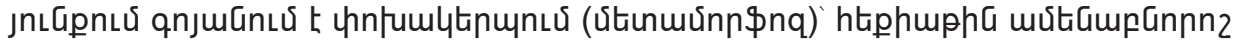
ttqumnбmumG hGunn: 